Jỗo Francisco NAVES da FonSECA

\title{
EXAME DOS FATOS NOS RECURSOS EXTRAORDINÁRIO E ESPECIAL
}

\author{
Dissertação de Mestrado \\ (versão simplificada - ref. Resolução CoPGr 5401, de 17 de abril de 2007)
}

Orientador: Professor CÂNDIDO RANGEL DINAMARCO

Departamento de Direito Processual

Faculdade de Direito da Universidade de São Paulo - Largo São Francisco

SÃO PAULO, 2010 


\section{RESUMO}

Título: "Exame dos fatos nos recursos extraordinário e especial"

Palavras-chave: recurso de direito estrito - recurso extraordinário - recurso especial - fatos

Equivoca-se quem pensa que o Supremo Tribunal Federal e o Superior Tribunal de Justiça devem ficar totalmente alheios aos fatos nos julgamentos dos recursos extraordinário e especial. Primeiro porque é a partir do suporte fático delineado no acórdão recorrido que se realiza a importante função de controlar a aplicação do direito. Segundo - e principalmente - porque é a própria Constituição que determina aos tribunais de superposição, após a superação do prévio juízo de admissibilidade, o rejulgamento da causa subjacente aos recursos de direito estrito, para o qual obviamente o exame de matéria fática é indispensável. Isso não significa, contudo, que o exame dos fatos em recursos extraordinário e especial seja irrestrito. Ao contrário, por conta dos escopos institucionais e da marca de excepcionalidade desses recursos, a incursão em matéria fática na instância de superposição encontra mais limites do que nas instâncias ordinárias.

O presente trabalho tem, assim, o escopo de definir os aludidos limites ao exame de matéria fática na instância de superposição. Para tanto, na parte inicial da dissertação, são apresentados o recurso extraordinário e o especial, realçando as características que os identificam como recursos de direito estrito. Merecem destaque também as funções institucionais desses recursos, cuja análise sistemática revela que elas efetivamente se interrelacionam na aplicação do direito à espécie, a ponto de o êxito de uma depender do sucesso das demais.

Em seguida, aborda-se a dicotomia fato e direito. Nesse capítulo, após o estudo das dificuldades do assunto, inclusive no que tange à subsunção do fato às normas denominadas abertas, conclui-se que, ao menos para efeito de admissibilidade dos 
recursos extraordinário e especial, a distinção entre questão de fato e questão de direito é possível e bastante útil.

Mais adiante, adentra-se no cerne do trabalho. Nele, são aplicadas as premissas assentadas nos capítulos antecedentes, a fim de entender e melhor dimensionar a vedação ao reexame dos fatos na instância de superposição. Inicialmente, tal vedação é conciliada com a natureza de corte de revisão dos tribunais de superposição brasileiros, sempre à luz das suas funções institucionais e dos princípios processuais consagrados na Constituição. Após a fixação dos limites ao julgamento da causa nos recursos extraordinário e especial, direciona-se o foco do estudo para o cabimento desses recursos. São analisados, assim, dois tipos de erro frequentemente impugnados pelos recursos de direito estrito: o cometido na qualificação jurídica do fato e aquele perpetrado na valoração jurídica da prova. Por fim, ainda com a atenção especialmente voltada para o juízo de admissibilidade, são traçados os limites da revisão - na instância de superposição - da rejeição liminar da demanda (CPC, art. 285-A), do julgamento antecipado do mérito (CPC, art. 330) e da tutela de urgência. 


\section{RIASSUNTO}

Titolo: "Esame dei fatti nei ricorsi 'extraordinário' e 'especial"”

Parole-chiavi: ricorso di diritto - "recurso extraordinário" - "recurso especial" - fatti

Si sbaglia chi pensa che il "Supremo Tribunal Federal" e il "Superior Tribunal de Justiça" devono restare al di fuori dei fatti nei giudizi dei ricorsi "extraordinário" e "especial". Inanzitutto perché è dal supporto fattico delineato nella decisione oggetto del ricorso che si realizza l'importante funzione di controllare l'applicazione del diritto. D'altra parte - e principalmente - perché è la propria Costituzione Federale che determina ai tribunali superiori, dopo il giudizio previo di ammissibilità dei ricorsi "recurso extraordinário" e "especial", il riesame della causa, per il quale ovviamente l'esame di materia fattica è indispensabile. Ciò non significa, comunque, che l'esame dei fatti in ricorsi "extraordinário" e "especial" sia irristretto. Al contrario, dovuto agli scopi istituzionali e alla impronta di eccezionalità di questi ricorsi, l'incursione in materia fattica nell'istanza superiore trova più limiti che nelle istanzi ordinarie.

Il presente lavoro ha, altresì, lo scopo di definire i menzionati limiti all'esame di materia fattica nell'istanza superiore. Per tanto, nella parte iniziale della dissertazione sono presentati il "recurso extraordinário" e il "recurso especial", richiamando gli assetti che li identificano come ricorsi di diritto. Meritano rilievo inoltre le funzioni istituzionali di questi ricorsi, la cui analisi sistematica rileva che esse effetivamente si relazionano nell'applicazione del diritto alla specie, al punto dall'esito di una dipendere il sucesso delle altre.

In seguito, l'approccio è sulla dicotomia fatto e diritto. In questo capitolo, dopo lo studio delle difficoltà dell'assunto, incluso in quel che si riferisce all'applicazione di norme elastiche, si conclude che, almeno per l'effetto di ammissibilità dei 
ricorsi "extraordinário" e "especial", la distinzione fra questione di fatto e questione di diritto è possibile e piuttosto utile.

Più avanti, ci si arriva alla parte centrale del lavoro. Lì, sono messe in atto le premesse basate nei capitoli precedenti, con la finalità di capire e meglio dimensionare il divieto al riesame dei fatti nell'istanza superiore. In un primo momento, tale divieto è conciliato con la natura di corti di revisione del "Supremo Tribunal Federal" e del "Superior Tribunal de Justiça", sempre alla luce delle loro funzioni istituzionali e dei principi processuali consacrati nella Costituzione. Dopo fissare i limiti al giudizio della causa nei ricorsi "extraordinário" e "especial", si rivolge il mirino dello studio all' ammissibilità di questi ricorsi. Sono analizzati, così, due tipi di errore spesso impugnati dai ricorsi di diritto: quello comesso nella qualificazione giuridica del fatto e quello effettuato nella valutazione giuridica della prova. Alla fine, ancora con l'attenzione specialmente rivolta al giudizio di ammissibilità, sono tracciati i limiti della revisione - nell'istanza superiore - del rigetto liminare della domanda (CPC, art. 285-A), del giudizio antecipato del merito (CPC, art. 330) e della tutela d'urgenza. 


\section{INTRODUÇÃO}

\section{APRESENTAĊ̃̃o}

\section{OBJETO E ESTRUTURA DO TRABALHO}

A vida dos direitos é regida por fatos. Daí o provérbio ex facto oritur ius, que literalmente significa "o direito nasce dos fatos". As próprias normas jurídicas não são outra coisa senão a previsão valorativa e abstrata de fatos tipificados com maior ou menor precisão, seguida da determinação de um efeito que deve incidir sempre que aquela fattispecie se realizar concretamente, dando origem a direitos subjetivos. Aliás, não é só o nascimento destes que depende de fatos, mas todo o seu desenvolvimento até a sua extinção. ${ }^{1}$ Assim, na medida em que só se cria, se altera ou se extingue uma situação jurídica com a interferência de um fato relevante, o demandante, no processo civil, tem o ônus de afirmar os fatos que sustentam a sua pretensão (fatos constitutivos do seu direito), e o réu tem o ônus de invocar os fatos que justificam a sua resistência àquela (fatos impeditivos, modificativos ou extintivos do direito do autor). ${ }^{2} \mathrm{E}$ mais, além desses fatos diretamente relacionados com o direito material, há outros cuja afirmação em determinado momento também constituem ônus dos litigantes, mas cuja eficácia é restrita ao próprio processo (v.g., a localização do imóvel em uma comarca é fato constitutivo da competência do foro em que ele está situado). ${ }^{3}$

Igualmente expressam a importância dos fatos para a prestação da tutela jurisdicional duas outras máximas: narra mihi factum dabo tibi ius e iura novit curia.

\footnotetext{
${ }^{1} \mathrm{Na}$ verdade, em todo e qualquer fenômeno jurídico, há necessariamente um fato subjacente, um valor que confere significado a esse fato e, obviamente, uma norma de direito, que reproduz a integração entre o fato e o valor (cf. Miguel ReAle, Filosofia do direito, n. 195, p. 448; Lições preliminares de direito, cap. XV, p. 194195).

${ }^{2}$ Pode o réu também se limitar a negar os fatos constitutivos do direito do autor, sem alegar outros impeditivos, modificativos ou extintivos deste.

${ }^{3}$ Cf. CÂNDIDO DinAmARCO, Instituições de direito processual civil, II, n. 450, p. 126 e n. 524, p. 253255; e III, n. 1.066, p. 464.
} 
A primeira, "narra-me o fato e dar-te-ei o direito", indica que os fundamentos jurídicos alegados pelo autor não passam de mera sugestão endereçada ao juiz, ao qual compete enquadrar os fatos narrados e provados nas categorias jurídicas adequadas, de maneira que a estabilização da causa de pedir toca somente aos seus fundamentos fáticos. Em sentido semelhante, a segunda máxima, "a Corte conhece o direito", acaba retirando do demandante o rigor do ônus de invocar precisamente as normas jurídicas aplicáveis aos fatos narrados, ao indicar que o juiz tem liberdade para aplicá-las conforme seu entendimento. Note-se que esse provérbio nada diz sobre os fatos, pela simples razão de que quanto a estes a parte tem o ônus absoluto de afirmação, sob pena de não serem levados em conta pelo julgador no momento de decidir. ${ }^{4} 5$

De um modo geral, portanto, no processo civil brasileiro, as alegações fáticas dos litigantes vinculam o juiz. Mas antes de aplicar o direito objetivo ao caso concreto, ele deve dirimir as dúvidas referentes a tais alegações; deve, em outras palavras, fixar os fatos sobre os quais as normas jurídicas hão de incidir. Após resolver todas as questões relevantes para o julgamento da causa, aí sim o juiz deve proferir a sentença. Contra essa decisão, os litigantes podem interpor apelação, impugnando tanto as questões de fato quanto as de direito; o tribunal local, por sua vez, tem liberdade para revisar a sentença integralmente, podendo inclusive dar soluções diversas a cada uma daquelas questões, obviamente dentro dos limites da devolução recursal (CPC, arts. 505 e 515, caput e $\S \S)$. Exaurido o julgamento em segundo grau de jurisdição, o sistema processual ainda faculta ao litigante inconformado a interposição dos recursos especial e extraordinário, conforme o caso. Ocorre que, nesses recursos, os fatos não mais podem ser impugnados, pois a Constituição Federal cuidou de vincular o seu cabimento a determinadas quaestiones iuris. Todavia, ao mesmo tempo em que o texto constitucional excluiu as questões fáticas do âmbito

\footnotetext{
${ }^{4}$ Cf. CÂNDIDo DinAmarco, Vocabulário do processo civil, n. 228, p. 318 e n. 329, p. 352; Instituições de direito processual civil, II, n. 416, p. 71 e n. 450, p. 127-128. Cf. tb. CARLOS Alberto CARMONA, "Em torno da petição inicial", p. 20.

${ }^{5}$ Em razão disso, para MiCHELI, "o ponto central de qualquer processo é a formação do convencimento do juiz, a respeito dos fatos da causa" ("Teoria Geral da Prova”, p. 161). Em sentido semelhante, KAZUO WATANABE ensina que "na equação do problema jurídico, o dado de direito é, evidentemente, de grande importância, mas relevância superlativa tem o dado fático” (Da cognição no processo civil, n. 13, p. 72).
} 
de controle dos tribunais de superposição, ${ }^{6}$ ele conferiu a estes competência para o julgamento da causa subjacente aos recursos de direito estrito, dando-lhes assim natureza de cortes de revisão (arts. 102, inc. III, e 105, inc. III).

Ao restringir a tipicidade do erro passível de ser impugnado a questões constitucionais e federais infraconstitucionais, a Constituição estabeleceu a importantíssima função dos recursos extraordinário e especial de controlar a aplicação da norma jurídica. Não obstante, equivoca-se quem pensa que o Supremo Tribunal Federal e o Superior Tribunal de Justiça devem ficar totalmente alheios aos fatos nos julgamentos desses recursos. Primeiro porque é a partir do suporte fático delineado no acórdão recorrido que se realiza o controle da aplicação do direito. Segundo - e principalmente - porque, como já dito, é o próprio texto constitucional que determina aos tribunais de superposição, após a superação do prévio juízo de admissibilidade, o rejulgamento da causa, para o qual obviamente o exame de matéria fática é indispensável.

Isso não significa, entretanto, que o exame dos fatos em recursos extraordinário e especial seja irrestrito. Ao contrário, por conta dos escopos institucionais e da marca de excepcionalidade desses recursos, a incursão em matéria fática na instância de superposição encontra mais limites do que nas instâncias ordinárias. Contudo, muito embora sejam bem conhecidos os enunciados sumulares que expressam a vedação ao reexame dos fatos em sede de recursos de direito estrito (5 e 7 do STJ, e 279 e 454 do STF), ${ }^{7}{ }^{8}$ o papel dos fatos no julgamento desses recursos ainda é mal compreendido, não só no que tange ao juízo de admissibilidade, mas também no que diz respeito ao juízo de mérito da impugnação.

\footnotetext{
${ }^{6}$ Tribunais de superposição são aqueles que julgam recursos interpostos em causas que já tenham exaurido todos os graus das Justiças (comuns e especiais, se for o caso) de determinado país; por isso, é que se diz que eles se sobrepõem a elas. No Brasil, ostentam tal condição o Supremo Tribunal Federal (órgão de cúpula do Poder Judiciário) e o Superior Tribunal de Justiça. Nem um nem outro pertence a qualquer Justiça (cf. Cintra-Grinover-Dinamarco, Teoria Geral do Processo, n. 98, p. 178-179; CASTRo NunES, Teoria e prática do Poder Judiciário, p. 201; CÂNDIDO DINAMARCO, "A função das Cortes supremas na América Latina", p. 784; Instituições de direito processual civil, I, n. 160, p. 382).

7 “A simples interpretação de cláusula contratual não enseja recurso especial (5 do STJ)"; "A pretensão de simples reexame de prova não enseja recurso especial" (7 do STJ); "Para simples reexame de prova não cabe recurso extraordinário" (279 do STF); "Simples interpretação de cláusulas contratuais não dá lugar a recurso extraordinário" (454 do STF).

${ }^{8}$ Não se ignora a precisa observação de BARBOSA MOREIRA, no sentido de que a expressão correta é "Enunciado $\mathrm{n}^{\circ} x$ da Súmula da jurisprudência predominante do STF" ["A redação da Emenda Constitucional n 45 (Reforma da Justiça)", p. 42-43].
} 
O presente trabalho, por conseguinte, tem o escopo de definir os aludidos limites ao exame de matéria fática na instância de superposição. Para tanto, em um primeiro momento, serão apresentados o recurso extraordinário e o especial, enfatizando as características que os identificam como recursos de direito estrito. Merecerão destaque também as funções institucionais desses recursos, cuja análise sistemática revelará que elas efetivamente se inter-relacionam na aplicação do direito à espécie, a ponto de o êxito de uma depender do sucesso das demais.

Em seguida, será abordada a dicotomia fato e direito. Nesse capítulo, após o estudo das dificuldades do assunto, inclusive no que tange à subsunção do fato às normas denominadas abertas, concluir-se-á que, ao menos para efeito de admissibilidade dos recursos extraordinário e especial, a distinção entre questão de fato e questão de direito é possível e bastante útil.

Mais adiante, adentrar-se-á no cerne do trabalho. Nele, serão aplicadas as premissas assentadas nos capítulos antecedentes, a fim de entender e melhor dimensionar a vedação ao reexame dos fatos na instância de superposição. Inicialmente, tal vedação será conciliada com a natureza de corte de revisão dos tribunais de superposição brasileiros, sempre à luz das suas funções institucionais e dos princípios processuais consagrados na Constituição. Após a fixação dos limites ao julgamento da causa nos recursos extraordinário e especial, direcionar-se-á o foco do estudo para o cabimento desses recursos. Serão analisados, assim, dois tipos de erro frequentemente impugnados pelos recursos de direito estrito: o cometido na qualificação jurídica do fato e aquele perpetrado na valoração jurídica da prova. Por fim, ainda com a atenção especialmente voltada para o juízo de admissibilidade, serão traçados os limites da revisão - na instância de superposição - da rejeição liminar da demanda (art. 285-A), do julgamento antecipado do mérito (art. 330) e da tutela de urgência. 


\section{ENCERRAMENTO}

\section{DESFECHO}

\section{CONCLUSÕES}

Há uma ou mais conclusões praticamente em cada um dos tópicos desenvolvidos ao longo deste trabalho; todavia, à guisa de encerramento, relacionamse somente as principais:

1. A nomofilaquia, a uniformização da jurisprudência e a formação de precedentes são funções fundamentais exercidas pelos tribunais de superposição no julgamento dos recursos de direito estrito. São, ademais, tarefas que se realizam conjuntamente: corrigindo um error iuris, o tribunal fixa o sentido e o alcance do texto normativo, uniformiza o entendimento jurisprudencial e cria um precedente judicial, com poder persuasivo ou até vinculante. Contudo, no sistema recursal brasileiro, todas essas atividades só são possíveis se a parte recorrer para reverter uma decisão que lhe é desfavorável; são, nessa medida, dependentes do impulso do litigante em defender o seu próprio interesse.

2. Ao determinar o julgamento da causa subjacente aos recursos extraordinário e especial admitidos, a Constituição confere ao Supremo Tribunal Federal e ao Superior Tribunal de Justiça natureza de cortes de revisão. Por isso, em regra, se estes tribunais conhecem e dão provimento a recurso de direito estrito, eles (a) anulam a decisão impugnada e remetem o caso para a instância de origem, se verificam error in procedendo; ou $(b)$ julgam a causa, substituindo o acórdão recorrido, se corrigem error in iudicando. 
3. Os recursos extraordinário e especial têm sim a finalidade - inerente a todos os institutos e remédios processuais - de aprimorar decisões em vista do valor do justo. Registre-se, entretanto, que defender a inserção dos recursos de direito estrito na garantia do acesso à ordem jurídica justa não significa afirmar que os tribunais de superposição devam se transformar em terceira instância. Ao contrário, os requisitos de admissibilidade desses recursos devem sempre ser respeitados. Além disso, uma vez admitido o recurso, o tribunal de superposição ainda tem alguns limites para observar na etapa de rejulgamento da causa.

4. No processo decisório, é possível distinguir basicamente dois momentos nos quais o julgador recorre às regras de experiência. Inicialmente elas ajudam na formação das presunções judiciais e na valoração das provas produzidas para a apuração dos fatos. O segundo momento é o da subsunção do fato à norma aberta, que consiste na operação pela qual os fatos já apurados recebem, mediante o confronto com a hipótese legal elástica, a devida qualificação jurídica.

5. Embora no campo filosófico a distinção entre fato e direito - em alguns casos realmente se revele muito difícil, há várias razões técnico-processuais que recomendam a conservação da dicotomia. Portanto, mesmo admitindo que ontologicamente existam apenas questões predominantemente de fato ou predominantemente de direito, ou ainda que se reconheça que estes conceitos são puramente dogmáticos ou práticos, deve-se deixar claro que, ao menos para efeito de admissibilidade dos recursos extraordinário e especial, a distinção entre questão de fato e questão de direito é suficiente, útil e efetivamente possível.

6. Questão de fato é a dúvida que versa sobre a reconstituição histórica de acontecimentos ou sobre o correto entendimento de circunstâncias passadas ou presentes, cuja solução é relevante para o julgamento da causa.

7. Questão de direito é a dúvida referente à especificação ou à interpretação da norma jurídica que deve regular a base fática acertada. 
8. Nem toda quaestio iuris abre as portas da instância de superposição. Para tanto, é preciso haver uma questão constitucional ou uma questão federal infraconstitucional, conforme se trate de recurso extraordinário ou de recurso especial.

9. A não-interferência nas finalidades nomofilática e uniformizadora, assim como o próprio efeito daí decorrente (menor perniciosidade à coletividade), explica a exclusão do error facti in iudicando do rol de matérias controláveis em sede de recurso de direito estrito. A justificativa dogmática, todavia, é até mais simples: o cabimento dos recursos extraordinário e especial é limitado, respectivamente, às questões constitucionais e federais infraconstitucionais, porque a Constituição Federal assim estabelece (arts. 102, inc. III, $a-d$, e 105, inc. III, $a-c$ ).

10. Inobstante as funções nomofilática e uniformizadora predominarem no juízo de admissibilidade recursal, superado este juízo, o Supremo Tribunal Federal e o Superior Tribunal de Justiça - enquanto cortes de revisão - devem voltar a atenção também para a administração da justiça no caso concreto, que é outro fundamental escopo dos recursos extraordinário e especial. Na etapa de rejulgamento da causa, os tribunais de superposição podem até examinar - o que é diferente de reexaminar - questão de fato ainda não decidida, desde que respeite alguns limites.

11. A leitura dos enunciados sumulares que vedam o reexame de fato na instância de superposição revela a exigência de o recurso impugnar a solução de alguma quaestio iuris; ou seja, não é admissível recurso de direito estrito cujo objeto seja simples questão de fato. Tanto é assim que eles empregam expressões verbais ("caber", "ensejar" e "dar lugar a") ${ }^{9}$ que remetem à idéia de cabimento ou admissibilidade recursal. Além disso, empregam o adjetivo simples, qualificando a questão de fato que não pode ser objeto do recurso, para abrir as portas da via excepcional ao recorrente que não pretender apenas o exame de prova.

\footnotetext{
9 "Para simples reexame de prova não cabe recurso extraordinário" (279 do STF); "Simples interpretação de cláusulas contratuais não dá lugar a recurso extraordinário" (454 do STF)"; "A simples interpretação de cláusula contratual não enseja recurso especial (5 do STJ)"; "A pretensão de simples reexame de prova não enseja recurso especial" (7 do STJ).
} 
12. Superado o prévio juízo de admissibilidade, o tribunal de superposição deve julgar a causa com base em todos os elementos de prova constantes nos autos, ainda que não mencionados no acórdão recorrido, desde que respeite dois limites. $\mathrm{O}$ primeiro consiste na garantia do direito à prova, assegurado constitucionalmente pela cláusula do devido processo legal, de modo que se o julgamento integral da causa, após a fixação da tese jurídica correta, depender de prova ainda não produzida, o tribunal de superposição deve devolver os autos para que o juízo de primeira instância, ou o tribunal de origem, complete a instrução probatória e profira nova decisão. O segundo limite são os pontos de fato já decididos pelo tribunal local, porque este é soberano quanto à matéria fática decidida no acórdão - é vedado o reexame, não o exame.

13. Cabe uma ressalva quanto à correção de vício de atividade: se, ao invés de anular a decisão impugnada e devolver os autos para a instância de origem, o tribunal de superposição decidir por julgar a causa desde logo, os pontos de fato diretamente ligados ao error in procedendo podem receber outra conclusão na instância de superposição. Frise-se, porém, que o julgamento da causa in totum pelo tribunal de superposição, após a correção de error in procedendo, não deve ser a regra, por conta da necessidade de se preservarem as garantias do direito à prova, do contraditório e da ampla defesa.

14. É claro também que a dimensão horizontal da devolução no rejulgamento da causa depende da medida do êxito do recurso na etapa anterior. Em outras palavras, autorizase o julgamento da causa pelo tribunal de superposição apenas no que tange aos capítulos da decisão afetados pela correção do erro de direito. Por isso, a rigor, julga-se "a causa", mas dentro dos limites do provimento da impugnação.

15. Os tribunais de superposição brasileiros, ao darem provimento a recurso voltado contra acórdão contendo error in iudicando, devem reformá-lo, substituindo-o, nos limites em que conhecida a impugnação, pois não há - no direito positivo pátrio - regra que autorize expressamente o reenvio da causa para o tribunal de origem. Há entretanto princípios constitucionais, tais como o do direito à prova, o do contraditório e o da ampla defesa, que devem sempre ser observados. Por isso, se o julgamento integral da causa depender de provas ainda não produzidas, o tribunal deve devolver os autos para 
que o juízo de primeira instância, ou o tribunal local, complete a instrução e profira nova decisão, em atenção à cláusula do devido processo legal, mesmo em caso de vício de juízo. Portanto, somente nesses casos, o reenvio é permitido e independe de pedido recursal, por se tratar de reforma (e substituição) parcial do acórdão, porque limitada à matéria de direito, de modo que, se o tribunal pode o mais - que é julgar definitivamente a causa in totum -, deve também poder o menos: decidir parcialmente a lide e remeter os autos para providências de instrução e julgamento pelas instâncias inferiores. Todavia, se a instrução estiver completa e a causa madura, o tribunal de superposição deve julgá-la integralmente, em atenção aos princípios constitucionais da efetividade e da celeridade do processo, mas respeitando a soberania do tribunal local quanto à matéria fática decidida e as garantias do devido processo legal.

16. A qualificação jurídica do fato ocorre em momento posterior ao da sua fixação. Isso significa que o juiz primeiro decide qual versão dos fatos deve prevalecer para, em seguida, inseri-la em uma categoria jurídico-substancial adequada. Nessa segunda etapa, eventual erro de julgamento é sempre de direito, porque o enquadramento do fato em uma norma jurídica pressupõe necessariamente a sua interpretação.

17. A fim de viabilizar a revisão da qualificação jurídica do fato na instância de superposição, o recorrente não pode impugnar a solução do ponto fático, mas deve dirigir o seu inconformismo unicamente contra o seu enquadramento legal. Note-se que, para a admissibilidade do recurso, relevante é apenas a discussão nele veiculada, pouco importando o teor do aresto impugnado. Essa é a razão pela qual a afirmação de que o acórdão recorrido formou a sua convicção com base nas provas e circunstâncias fáticas próprias do caso sub judice não pode servir como justificativa para obstar recurso extraordinário ou especial. Aliás, o natural é que a decisão tenha mesmo se formado a partir das provas e circunstâncias fáticas dos autos.

18. A subsunção do fato a qualquer tipo de norma - inclusive às abertas - é sempre questão de direito.

19. A compensação do dano moral está prevista, no direito brasileiro, em uma espécie de norma jurídica aberta, já que o legislador não forneceu nenhum critério para delimitar 
os valores da indenização. Assim, nas situações em que, pelos próprios dados afirmados no acórdão do tribunal local, ficar patente o erro na aplicação da norma aberta ao caso concreto, o recurso deve ser admitido para, desde logo, excluir a indenização por danos morais, arbitrá-la, ou redimensionar o seu montante, conforme o caso.

20. O recurso especial não é a via apropriada para alegar que o tribunal a quo arbitrou os honorários advocatícios sem levar em consideração o cuidado dispensado pelo patrono da parte na defesa da causa, tampouco para discutir a importância desta ou qualquer outra circunstância fática que pudesse ter influenciado na quantia fixada. Por outro lado, se a impugnação é dirigida contra acórdão que fixou os honorários advocatícios "consoante apreciação eqüitativa" (CPC, art. 20, § $4^{\circ}$ ), o seu conhecimento passa a depender dos mesmos fatores que condicionam o conhecimento de recurso de direito estrito que alega violação a qualquer norma aberta. Idêntica solução vale para a alegação de vício na especificação do sentido e alcance da expressão "parte mínima do pedido" (CPC, art. 21, § ún.). Nesses casos, o recurso especial apenas poderá ser conhecido se o erro na qualificação jurídica dos fatos puder ser verificado a partir das premissas fáticas estabelecidas no próprio acórdão atacado.

21. Qualquer revisão de indenização de lucros cessantes por tribunal de superposição seja para excluí-la, fixá-la ou redimensionar o seu montante -, só é viável na medida em que a inadequação da consequência jurídica atribuída aos fatos puder ser constatada a partir das premissas fixadas pelo próprio acórdão atacado.

22. Quanto às cláusulas contratuais, é vedada a averiguação em torno da declaração de vontade - desde sua existência e forma de emissão (se, v.g., oral ou escrita) até a investigação da intenção real (psicológica) das partes. Não obstante isso, é possível a revisão da compatibilidade do contrato com o ordenamento jurídico estatal, na medida em que esse controle prescinde do reexame de fatos.

23. A valoração jurídica da prova é típica quaestio iuris, porque consiste no confronto dos elementos de prova com as regras instituídas pelo direito objetivo em relação a eles. 
24. Qualquer questão envolvendo a licitude da prova é eminentemente jurídica, razão pela qual podem ser atacados por recurso de direito estrito tanto o acórdão do tribunal local que excluiu a eficácia de prova por considerá-la ilícita quanto o aresto que admitiu alguma prova sem conceituá-la como ilícita - ou que utilizou prova ilícita aplicando o princípio da proporcionalidade.

25. São tipicamente jurídicas as questões que discutem a eficácia, a aptidão ou a inaptidão de determinado meio de prova, tenha este sido utilizado ou tenha sido preterido pelo julgador.

26. Nos casos em que a obrigatoriedade da prova pericial decorre - direta ou indiretamente - de imposição legal, o acórdão que dispensa a sua produção pode ser impugnado por recurso especial. Por outro lado, se realizada a perícia, a liberdade do juiz de formar a sua convicção exclusivamente com fundamento em outros meios de prova está condicionada à explicação dos motivos pelos quais o resultado da prova técnica não foi acolhido pela decisão, sob pena de violar os direitos à fundamentação suficiente e à prova, assim como, no particular, as disposições que regulam a prova pericial.

27. A aplicação dos preceitos normativos que restringem ou excluem a eficácia da prova testemunhal pode ser discutida em recurso especial, na medida em que não se questiona a credibilidade nem o conteúdo do depoimento.

28. Se o tribunal de origem admite prova diversa da documental no rito do mandado de segurança, surge uma questão de direito probatório possível de ser dirimida em recurso de direito estrito. Ressalvada essa hipótese, que tem a ver exclusivamente com a valoração jurídica da prova, os recursos extraordinário e especial não se prestam para controlar a convicção formada no tribunal de origem a respeito de ser ou não o "direito liquido e certo".

29. A questão da "prova escrita" no procedimento monitório é eminentemente de direito, pois diz respeito à subsunção de um fato incontroverso - uma declaração de vontade 
ou outro documento qualquer - no conceito jurídico elástico "prova escrita sem eficácia de título executivo".

30. Submete-se ao crivo de recurso especial o acórdão que dispensa o instrumento público nas hipóteses em que a lei o exija como condição para a própria constituição da relação de direito material (CPC, art. 366).

31. Tendo em vista que a simples questão da correção ou incorreção de uma regra de experiência - isoladamente tomada - nada tem de jurídica, o controle do seu emprego, enquanto instrumento de apuração e avaliação dos fatos, não pode ser objeto de recurso extraordinário ou especial. Assim, é possível o controle (indireto) das presunções judiciais somente nas hipóteses em que o acórdão recorrido haja violado alguma norma de direito probatório.

32. Os recursos de direito estrito não se prestam para revisar os fatos já definidos pelo tribunal de origem, sejam eles notórios ou não. Tampouco, em regra, o conceito de notoriedade pode ser controlado pelos tribunais de superposição, tendo em vista não só a sua grande relatividade cultural, espacial e temporal, mas também a inevitabilidade da investigação de elementos fáticos para preenchê-lo no caso concreto, os quais dificilmente estariam - todos eles - detalhados no aresto recorrido. É inadmissível, portanto, o recurso especial que queira rediscutir a convicção devidamente fundamentada a respeito da notoriedade do fato, tenha esta exigido prova ou não para ser formada, porque ela é uma qualidade do fato que é verificada no momento e na localidade em que a decisão é prolatada.

33. Há de se fazer a distinção entre recurso impugnando acórdão que nega efeito à confissão ou que a ela dê efeito pleno, desconsiderando o conjunto probatório, e recurso contra decisão que valora a confissão como um dos elementos integrantes do livre convencimento motivado. Este não levanta nenhuma tese geral, desprendida do caso concreto, e quer somente a reavaliação do conjunto probatório, por isso não deve ser admitido; aquele, ao contrário, deve ser conhecido, pois discute uma questão de direito: o valor e a eficácia da prova em abstrato. 
34. No tocante ao ônus de impugnação especificada dos fatos (CPC, art. 302), se o autor alega um fato que pareça ao juiz impossível ou improvável e este exige daquele a prova do alegado, não há por parte do órgão judicial nenhuma violação a regra de direito probatório; idem se o julgador dispensa a prova, entendendo que o fato não impugnado é possível ou provável. Em ambos os casos, não há nenhum tipo de quaestio iuris, na medida em que a decisão comporta-se nos parâmetros do poder de livre convencimento motivado do juiz. Por outro lado, suponha-se que o acórdão do tribunal local, para presumir um fato como verdadeiro - ou para afastar a presunção -, enfrentou a questão da admissibilidade da confissão em relação a este (CPC, art. 302, inc. I) ou tratou da necessidade de a petição inicial estar acompanhada de instrumento público que a lei considera da substância do ato (CPC, art. 302, inc. II). Nessas hipóteses, o recurso especial dirigido contra o aresto discute somente as ressalvas legais, cuja aplicação é passível de controle pelo Superior Tribunal de Justiça, porquanto trata-se de típica matéria jurídica. Já a exceção trazida pelo inc. III do art. 302 requer um pouco mais de atenção. A falta de impugnação do fato sancionada neste dispositivo legal é a que se refere à sua ausência no processo, de modo que se na contestação o réu não nega especificadamente uma alegação fática da inicial, mas ele o faz na reconvenção - ou na peça de denunciação a lide, ou na de chamamento ao processo etc. -, o fato torna-se controvertido para todos os efeitos. Nessa última hipótese, o recurso especial só será conhecido se restar evidente a violação ao dispositivo legal, a partir das próprias premissas e conclusões estabelecidas no acórdão atacado.

35. Os recursos de direito estrito não são a via adequada para controlar a conclusão do acórdão do tribunal local a respeito da verossimilhança da alegação, exigida para inverter o ônus da prova a favor do consumidor (CDC, art. $6^{\circ}$, inc. VIII). Também depende de incursão no material probatório dos autos a verificação dos fatos que podem configurar a hipossuficiência técnica do consumidor em relação a algum ponto controvertido da causa. Isso não significa, contudo, que seja vedado ao tribunal de superposição, partindo da base fática afirmada no próprio acórdão recorrido, controlar a aplicação do dispositivo legal, por exemplo, para afirmar que a hipossuficiência que se exige é a técnica ou para definir se os requisitos para tal aplicação - verossimilhança 
e assimetria de informação - são cumulativos ou alternativos. É que, nesses casos, impugna-se somente a interpretação dada pelo tribunal local à norma jurídica, ao contrário do que sucede com o recurso que se volta contra a convicção formada a respeito da verossimilhança das alegações ou contra a fixação dos fatos aptos a configurar a hipossuficiência do consumidor.

36. Além de estar previsto no direito positivo e no Regimento Interno dos tribunais de superposição, o exame de fato superveniente em sede de recursos extraordinário e especial - amplamente no julgamento do mérito recursal e excepcionalmente no juízo de admissibilidade -, respeitado o devido processo legal, coaduna-se com a visão instrumentalista do processo, pois reconhece que este existe não para simplesmente proclamar teses de direito abstratas, mas sim para tutelar interesses jurídicos concretos.

37. Envolveria pretensão de simples reexame de prova o recurso que impugnasse a conclusão do tribunal local a respeito da coincidência entre os fatos descritos pelo autor e aqueles acertados nas sentenças usadas como precedentes no julgamento liminar de improcedência da demanda (CPC, art. 285-A). Isso vale tanto para a confirmação quanto para a anulação da sentença liminar, pois se o tribunal local entende que a matéria fática da demanda em julgamento é igual à dos casos invocados pelo juízo de primeiro grau, essa questão nada tem de jurídica; idem se o tribunal entende que o caso tem peculiaridades fáticas que desautorizam o julgamento liminar de improcedência da demanda. Entretanto e por outro lado, há matérias na rejeição prima facie do pedido que podem ser controladas pelos tribunais de superposição, pois independem de reexame dos fatos. Em primeiro lugar, podem ser objeto de recurso de direito estrito as questões relacionadas com a própria interpretação e aplicação do dispositivo legal em si. Além disso, é possível também a impugnação do efeito jurídico que o tribunal local entendeu derivar dos fatos acertados, seja para manter a improcedência da demanda, seja para julgá-la procedente. Nesse último caso, é o próprio mérito da causa que será objeto de recurso extraordinário ou especial, se a questão de fundo for, respectivamente, constitucional ou federal infraconstitucional.

38. A questão relativa à antecipação do julgamento do mérito (CPC, art. 330), a princípio, não pode ser objeto de recurso de direito estrito, na medida em que o seu controle 
depende da investigação da pertinência, relevância e necessidade tanto das provas produzidas quanto das pretendidas pelas partes. Entretanto, há casos excepcionais em que o acórdão que delibera sobre julgamento antecipado do mérito pode se submeter ao crivo de recurso de direito estrito. Isso porque o poder de livre convencimento do julgador não é absoluto, pois ele deve observar, além do dever de fundamentação, uma série de princípios e regras que disciplinam a formação da sua convicção a partir do exame e da valoração das provas. Assim, o julgamento antecipado do mérito que atropela uma exigência legal - v.g., de produção de prova pericial para determinado fato probando - pode ser corrigido na instância de superposição, em razão do referido error in procedendo. Suponha-se ainda que o juízo de primeiro grau tenha julgado antecipadamente a causa improcedente "por falta de provas". Se o acórdão do tribunal local confirma essa decisão, ele pode ser impugnado por recurso de direito estrito, que suscitará violação do direito à fundamentação suficiente, além de ofensa ao próprio art. 330, por conta de eventual cerceamento do direito à prova. Por fim, também é possível que o tribunal local incorra em violação de norma de direito processual quando delibera sobre julgamento antecipado do mérito diante do descumprimento do ônus de responder adequadamente (CPC, art. 330, inc. II). Nessa situação, as quaestiones iuris ligam-se principalmente às hipóteses nas quais, por força de lei, deixa de ser aplicável a presunção de veracidade das alegações fáticas não rebatidas (CPC, art. 302, incs. I a III e art. 320, inc. I a III).

39. Os recursos extraordinário e especial não se prestam para discutir a convicção formada nas instâncias ordinárias acerca da presença dos pressupostos legais para a concessão de medidas de urgência, pois envolveria reexame de questões fáticas e provisórias. Por outro lado, desde que satisfeitos os demais requisitos de admissibilidade, deve ser conhecido o recurso que veicule matéria diretamente ligada à própria disciplina legal da tutela de urgência, porque - nesse caso - a questão impugnada é jurídica e dotada de caráter definitivo. 


\section{BIBLIOGRAFIA}

ABBud, André de Albuquerque Cavalcanti. "O anteprojeto de lei sobre a repercussão geral dos recursos extraordinários", in Revista de Processo, n. 129, ano 30, nov./2005, p. 108.

ABRAHAM, Henry J. The judicial process, $7^{\mathrm{a}}$ ed., Nova Iorque-Oxford, Oxford University Press, 1998.

Alcalá-Zamora y Castillo, Niceto. Derecho procesal mexicano, t. II, México, Porrúa, 1977.

Amaral Santos, Moacyr. Prova judiciária no cível e comercial, v. I, 5a ed., São Paulo, Saraiva, 1983.

Aprigliano, Ricardo de Carvalho. A ordem pública no direito processual civil, tese de doutorado defendida na Faculdade de Direito do Largo São Francisco - Universidade de São Paulo, em 2010.

Arruda Alvim Netto, José Manuel de. "A EC n. 45 e o instituto da repercussão geral”, in Reforma do Judiciário: primeiras reflexões sobre a Emenda Constitucional n. 45/2004 (coord. Teresa ArRuda Alvim WambIer et al.), São Paulo, RT, 2005.

Assis, Araken de. Manual dos Recursos, $2^{\mathrm{a}}$ ed., São Paulo, RT, 2008.

AZZONI, Clara Moreira. Recurso especial e extraordinário: aspectos gerais e efeitos, São Paulo, Atlas, 2009. 
BALEEIRo, Aliomar. O Supremo Tribunal Federal, êsse outro desconhecido, Rio de Janeiro, Forense, 1968.

BARBI, Celso Agrícola. Do Mandado de Segurança, $11^{\text {a }}$ ed. (atualizada por Bernardo Pimentel Souza), Rio de Janeiro, Forense, 2008.

BARboSA MoreirA, José Carlos. “Alegação de compensação rejeitada no despacho saneador. Documento junto sem audiência da outra parte. Pedido de exibição de documento em poder de pessoa jurídica sediada no estrangeiro. Questão de qualificação jurídica: possibilidade de reexame mediante recurso extraordinário", in Temas de direito processual (segunda série), $2^{a}$ ed., São Paulo, Saraiva, 1988.

- "Antecipação da tutela: algumas questões controvertidas", in Temas de direito processual (oitava série), São Paulo, Saraiva, 2004.

. "A redação da Emenda Constitucional no 45 (Reforma da Justiça)”, in Revista Forense, v. 378, março-abril/2005, p. 39.

. "As presunções e a prova", in Temas de direito processual (primeira série), $2^{\mathrm{a}}$ ed., São Paulo, Saraiva, 1988.

Comentários ao Código de Processo Civil, V, 14ª ed., Rio

de Janeiro, Forense, 2008.

"Julgamento do recurso especial ex art. 105, III, 'a', da

Constituição da República: sinais de uma evolução auspiciosa", in Revista da Ajuris, v. 75, ano 26, set./1999, p. 57.

O novo processo civil brasileiro: exposição sistemática do procedimento, $27^{\mathrm{a}}$ ed., Rio de Janeiro, Forense, 2008.

. "Que significa 'não conhecer' de um recurso?", in Temas

de direito processual (sexta série), São Paulo, Saraiva, 1997.

- "Regras de experiência e conceitos juridicamente indeterminados", in Temas de direito processual (segunda série), $2^{\mathrm{a}}$ ed., São Paulo, Saraiva, 1988.

. "Restrições ilegítimas ao conhecimento dos recursos", in

Temas de direito processual (nona série), São Paulo, Saraiva, 2007. 
BARIONI, Rodrigo Otávio. Recursos extraordinário e especial em ação rescisória, tese de doutorado defendida na Faculdade de Direito da PUC-SP, em 2007.

Bedaque, José Roberto dos Santos. "Discricionariedade judicial”, in Revista Forense, v. 354, março-abril/2001, p. 187.

Tutela cautelar e tutela antecipada: tutelas sumárias e de urgência (tentativa de sistematização), 4ª ed., São Paulo, Malheiros, 2006.

BENETI, Sidnei Agostinho. "Assunção de competência e fast-track recursal”, in Revista de Processo, v. 171, ano 34, mai./09, p. 9.

BEZERRA, Márcia Fernandes. "O cabimento do recurso extraordinário contra acórdão que defere medida liminar e a Súmula 735 do STF”, in Os poderes do juiz e o controle das decisões judiciais - Estudos em homenagem à Professora Teresa Arruda Alvim Wambier (coord. José M. GARCiA MEdina et al.), São Paulo, RT, 2008.

BONDIOLI, Luis Guilherme Aidar. "A nova técnica de julgamento dos recursos extraordinário e especial repetitivos", in Revista Jurídica, v. 387, jan./10, p. 27. . Embargos de declaração, São Paulo, Saraiva, 2005. . "O julgamento liminar de improcedência da demanda da óptica do réu (art. 285-A do CPC)”, in Revista Jurídica, v. 367, maio/08, p. 11.

Saraiva, 2006.

O novo CPC: a terceira etapa da reforma, São Paulo,

BONício, Marcelo José Magalhães. Proporcionalidade e processo: a garantia constitucional da proporcionalidade, a legitimação do processo civil e o controle das decisões judiciais, São Paulo, Atlas, 2006.

BotTini, Pierpaolo Cruz. "Mecanismos de uniformização jurisprudencial e a aplicação da súmula vinculante”, in Revista dos Tribunais, v. 865, ano 96, nov./07, p. 20. 
Bove, Mauro. "La Corte di cassazione come giudice di terza istanza", in Rivista trimestrale di diritto e procedura civile, anno LVIII, n. 3, set./04, p. 947.

BRUSCHI, Gilberto Gomes; DONOSO, Denis. "Divergência jurisprudencial e recurso especial: cabimento e forma de interposição do recurso especial com fundamento no art. 105, III, alínea c, da Constituição”, in Revista Dialética de Direito Processual, v. 83, fev./2010, p. 44.

BuZAID, Alfredo. "A crise do Supremo Tribunal Federal", in Estudos de Direito, São Paulo, Saraiva, 1972.

"Nova conceituação do recurso extraordinário na Constituição do Brasil", in Estudos de Direito, São Paulo, Saraiva, 1972.

CAHAl, Yussef Said. Dano moral, 3ª ed., São Paulo, RT, 2005.

. Honorários advocatícios, 2ª ed., São Paulo, RT, 1990.

CAlamandrei, Piero. Elogio dei giudici scritto da un avvocato, 1989, trad. port. de Eduardo Brandão, Eles, os juízes, vistos por um advogado, São Paulo, Martins Fontes, 1995.

La cassazione civile, vol. I e II in Opere giuridiche, respectivamente vols. VI e VII, Napoli, Morano, 1976. Per la definizione del fatto notorio in Opere giuridiche, vol. V, Napoli, 1972.

Calmon de Passos, José Joaquim. Comentários ao Código de Processo Civil, III, 9a ed., Rio de Janeiro, Forense, 2005. . "O imoral nas indenizações por dano moral", in Dano moral e sua quantificação (coord. SÉrgio Augustin), $4^{\text {a }}$ ed., Caxias do Sul, Editora Plenum, 2007.

. "O recurso extraordinário e a Emenda n. 3 do Regimento Interno do Supremo Tribunal Federal”, in Revista de Processo, n. 5, ano 2, jan.-março/1977, p. 43. 
CALOGERo, Guido. La logica del giudice e il suo controllo in cassazione, Padova, CEDAM, 1937.

CAmbI, Eduardo; NALin, Paulo. "O controle da boa-fé contratual por meio dos recursos de estrito direito", in Aspectos polêmicos e atuais dos recursos cíveis - e outros meios de impugnação às decisões judiciais (coord. NELSON NERY JR. e TERESA ARRUdA AlviM WAMBIER), São Paulo, RT, 2003.

CARMOnA, Carlos Alberto. "Em torno da petição inicial", in Revista de processo, n. 119, ano 30, jan./05, p. 11. . "O sistema recursal brasileiro: breve análise crítica", in Aspectos polêmicos e atuais dos recursos (coord. EDUARDO PELLEGRINI DE ARRUDA ALVIM et al.), São Paulo, RT, 2000.

CARNEIRO, Athos Gusmão. Recurso especial, agravos e agravo interno, $5^{\mathrm{a}}$ ed., Rio de Janeiro, Forense, 2008.

CARnelutTi, Francesco. Diritto e processo, Nápoles, Morano, 1958.

Istituzioni del processo civile, $4^{\mathrm{a}}$ ed., trad. esp. de Santiago Sentís Melendo, Instituciones del proceso civil, v. I, Buenos Aires, El Foro, 1997. Sistema di diritto processuale civile, v. I, Padova, CEDAM, 1936.

Carvalho, Fabiano. "Sobre a realização de nova perícia", in Provas: aspectos atuais do direito probatório (coord. DANIEL NEVES), Rio de Janeiro, Forense; São Paulo, Método; 2009.

CASTANHeIRA Neves, António. Questão-de-facto-questão-de-direito ou o problema metodológico da juridicidade (ensaio de uma reposição crítica), Coimbra, Almedina, 1967. 
Chiovenda, Giuseppe. Istituzioni di diritto processuale civile, v. I e III, trad. port. de J. Guimarães Menegale e notas de Enrico Tullio Liebman, Instituições de direito processual civil, v. I e III, $3^{\text {a }}$ ed., São Paulo, Saraiva, 1969. Principii di diritto processuale civile, $3^{\mathrm{a}}$ ed., Nápoles, Jovene, 1923.

CHRISTIE, George C. "Judicial review of findings of fact", in Northwestern University Law Review, n. 87, 1992, p. 14.

Cintra, Antônio Carlos de Araújo; Grinover, Ada Pellegrini; Dinamarco, Cândido Rangel. Teoria Geral do Processo, 19ª ed., São Paulo, Malheiros, 2003.

Comoglio, Luigi Paolo; Ferri, Corrado; TARuffo, Michele. Lezioni sul processo civile, v. I, $4^{\mathrm{a}}$ ed., Bologna, Il Mulino, 2006.

COMPARATO, Fábio Konder. "Reflexões sobre a dissolução judicial de sociedade anônima por impossibilidade de preenchimento do fim social", in Revista de Direito Mercantil, Industrial, Econômico e Financeiro, ano XXXIII, n. 96, out.-dez./1994.

Cooley, Thomas M. A treatise on the constitutional limitations: which rest upon the Legislative Power of the States of the American Union, Boston, Little, Brown \& Company, 1868.

Couture, Eduardo J. Fundamentos del derecho procesal civil, $3^{\mathrm{a}}$ ed., Buenos Aires, Depalma, 1976.

CRetella Júnior, José. Do mandado de segurança, São Paulo, Bushatsky, ed. USP, 1974. 
CRUZ E TucCI, José Rogério. A motivação da sentença no processo civil, São Paulo, Saraiva, 1987. . "Prova escrita na ação monitória", in Revista Magister de direito civil e processual civil, v. 1, jul.-ago./04, p. 30.

CunHA, Leonardo José Carneiro da. "Primeiras impressões sobre o art. 285-A do CPC julgamento imediato de processos repetitivos: uma racionalização para as demandas de massa", in Revista Dialética de Direito Processual, v. 39, jun./06, p. 93.

CunHA, Leonardo José Carneiro; DIDIER JúNIOR, Fredie. Curso de direito processual civil, $5^{\mathrm{a}}$ ed., v. 3, Salvador, JusPodivm, 2008.

DANTAS, Bruno. Repercussão Geral: perspectivas histórica, dogmática e de direito comparado. Questões processuais, São Paulo, RT, 2008.

Dezorzi, Diego; Schwartz, Germano. "A história da Corte Suprema no Brasil: da Casa da Suplicação até a criação do Supremo Tribunal Federal", in Revista da Ajuris, v. 112, ano 35, dez./08, p. 101.

DIDIER JÚNIOR, Fredie. "Julgamento de causas repetitivas: improcedência prima facie", in $A$ terceira etapa da reforma processual civil: comentários às Leis $n$. 11.187/2005, 11.232/2005, 11.276/2006, 11.280/2006 (Jorge, Flávio Cheim; DidIER JR., Fredie; ABELHA, Marcelo), São Paulo, Saraiva, 2006.

Didier JÚNIOR, Fredie; CUnHA, Leonardo José Carneiro. Curso de direito processual civil, $5^{\mathrm{a}}$ ed., v. 3, Salvador, JusPodivm, 2008. 
DiNAMARCO, Cândido Rangel. "Ação rescisória e interpretação contratual”, in Fundamentos do processo civil moderno, t. II, $3^{\mathrm{a}}$ ed., São Paulo, Malheiros, 2000.

. "A função das Cortes supremas na América Latina", in Fundamentos do processo civil moderno, t. II, $3^{\mathrm{a}}$ ed., São Paulo, Malheiros, 2000.

. Capítulos de sentença, $1^{\mathrm{a}}$ ed., São Paulo, Malheiros, 2002.

. "Direito e processo", in Fundamentos do processo civil moderno, t. I, $3^{\text {a }}$ ed., São Paulo, Malheiros, 2000.

Instituições de direito processual civil, I, 6a ed., São Paulo,

Malheiros, 2009.

Instituições de direito processual civil, II, $5^{\mathrm{a}}$ ed., São Paulo,

Malheiros, 2005.

. Instituições de direito processual civil, III, São Paulo,

Malheiros, 2001.

. "O efeito devolutivo da apelação e de outros recursos", in Nova era do processo civil, $2^{\mathrm{a}}$ ed., São Paulo, Malheiros, 2007.

. "O regime jurídico das medidas urgentes", in Nova era do processo civil, $2^{\mathrm{a}}$ ed., São Paulo, Malheiros, 2007.

. "Os efeitos dos recursos", in Nova era do processo civil,

$2^{\mathrm{a}}$ ed., São Paulo, Malheiros, 2007.

. "Segunda perícia e direito à prova", in Fundamentos do processo civil moderno, t. I, $3^{\mathrm{a}}$ ed., São Paulo, Malheiros, 2000.

. "Superior Tribunal de Justiça e acesso à ordem jurídica justa", in Revista de Processo, n. 59, ano 15, jul.-set./1990, p. 14.

. Vocabulário do processo civil, São Paulo, Malheiros, 2009.

Dinamarco, Cândido Rangel; CinTra, Antônio Carlos de Araújo; GrinOver, Ada Pellegrini. Teoria Geral do Processo, 19ª ed., São Paulo, Malheiros, 2003.

DinIZ, Maria Helena. Curso de direito civil brasileiro, v. 7, 16 ed., São Paulo, Saraiva, 2002. 
Donoso, Denis; BRUSCHI, Gilberto Gomes. "Divergência jurisprudencial e recurso especial: cabimento e forma de interposição do recurso especial com fundamento no art. 105, III, alínea c, da Constituição", in Revista Dialética de Direito Processual, v. 83, fev./2010, p. 44.

ENGISCH, Karl. Einführung in das juristiche denken, $8^{\text {a }}$ ed., Stuttgart, W. Kohlhammer, 1983, trad. port. de J. Baptista Machado, Introdução ao pensamento jurídico, 10 ${ }^{\mathrm{a}}$ ed., Lisboa, Fundação Calouste Gulbenkian, 2008.

FAZZALARI, Elio. Il giudizio civile di cassazione, Milano, Giuffrè, 1960.

FERrand, Frédérique; GuINChARD, Serge. Procédure civile: Droit interne et droit communautaire, $28^{\mathrm{a}}$ ed., Paris, Dalloz, 2006.

FERraZ JR., Tercio Sampaio. Introdução ao estudo do direito: técnica, decisão, dominação, São Paulo, Atlas, 2001.

Ferri, Corrado; TARUfFo, Michele; Comoglio, Luigi Paolo. Lezioni sul processo civile, v. I, $4^{\mathrm{a}}$ ed., Bologna, Il Mulino, 2006.

FONSECA, João Francisco Naves da. "A interpretação da sentença civil”, in Revista Dialética de Direito Processual, n. 62, maio/2008, p. 42.

. "Efeito devolutivo na apelação e 'questões de ordem pública"”, in Revista Brasileira de Direito Processual, n. 64, out.-dez./2008, p. 85.

. "O julgamento liminar de improcedência da demanda (art. 285-A): questões polêmicas", in Tutelas diferenciadas como meio de incrementar a efetividade da prestação jurisdicional (coord. HUMBERTO THEODORO JR. e MAIRA TERRA LAUAR), Rio de Janeiro, GZ (no prelo).

FONTOURA, Lúcia Helena Ferreira Palmeiro da. Recurso Especial: questão de fato/questão de direito, Porto Alegre, Fabris, 1993. 
FRANCO, Fernão Borba. "Vicissitudes do duplo grau de jurisdição: o art. 515, § $3^{\circ}$, do CPC", in Os poderes do juiz e o controle das decisões judiciais - Estudos em homenagem à Professora Teresa Arruda Alvim Wambier (coord. José M. GARCIA MedinA et al.), São Paulo, RT, 2008.

GALGANO, Francesco. La globalizzazione nello specchio del diritto, Bologna, il Mulino, 2005.

GAMBINERI, Beatrice. Giudizio di rinvio e preclusione di questioni, Milano, Giuffrè, 2008.

Garcia, André Almeida. Prova Civil, São Paulo, Saraiva, 2009.

GARCÍA FAÍlDE, Juan José. Nuevo derecho procesal canónico: estudio sistemático-analítico comparado, $3^{\text {a }}$ ed., Salamanca, Universidad Pontificia de Salamanca, 1995.

GouvÊA, José Roberto Ferreira; SILVA, Vanderlei Arcanjo da. "Quantificação dos danos morais pelo Superior Tribunal de Justiça", in Dano moral e sua quantificação (coord. SÉRGIO Augustin), $4^{\text {a }}$ ed., Caxias do Sul, Editora Plenum, 2007.

GouvÊA, José Roberto Ferreira; NEGRÃo, Theotonio; BondiolI, Luis Guilherme Aidar (com a colaboração de). Código de Processo Civil e legislação processual em vigor, $41^{\mathrm{a}}$ ed., São Paulo, Saraiva, 2009.

Código Civil e legislação civil em vigor, $28^{\mathrm{a}}$ ed., São Paulo, Saraiva, 2009.

GreCo, Leonardo. "Publicismo e privatismo no processo civil", in Revista de Processo, v. 164, ano 33, out./08, p. 29.

GreCo FILHO, Vicente. Direito processual civil brasileiro, 17 a ed, São Paulo, Saraiva, 2007. 
GrinOver, Ada Pellegrini. "Litisconsórcio necessário e efeito devolutivo do recurso especial", in O processo - Estudos e pareceres, São Paulo, Perfil, 2005. . "O controle do raciocínio judicial pelos tribunais superiores brasileiros", in Revista da Ajuris, v. 50, ano 17, nov./90, p. 5. . "O julgamento antecipado da lide: enfoque constitucional", in Revista de Processo, v. 5, ano 2, jan.-mar./77, p. 101.

Grinover, Ada Pellegrini; Dinamarco, Cândido Rangel; Cintra, Antônio Carlos de Araújo. Teoria Geral do Processo, 19ª ed., São Paulo, Malheiros, 2003.

GuASCH FERNÁNDEZ, Sergi. El hecho y el derecho en la casación civil, Barcelona, José María Bosch, 1998.

GuAsP, Jaime. Derecho procesal civil, t. II, $3^{\mathrm{a}}$ ed., Madrid, Instituto de Estudios Políticos, 1968.

GuInCHARD, Serge; FERRAND, Frédérique. Procédure civile: Droit interne et droit communautaire, $28^{\mathrm{a}}$ ed., Paris, Dalloz, 2006.

HABSCHEID, Walter J. Introduzione al diritto processuale civile comparato, Rimini, Maggioli, 1985.

Hamilton, Alexander; Madison, James; JAY, John. The federalist on the new Constitution, written in the year 1788, Hallowell, Glazier, Masters \& Smith, 1837.

HENKE, Horst-Eberhard. Der unbestimmte Begriff im Zivilrecht und seine Revisibilität, Berlim, Duncker \& Humblot, 1966, trad. esp. de T. A. Banzhaf, La cuestion de hecho. El concepto indeterminado en el derecho civil y su casacionabilidad, Buenos Aires, EJEA, 1979. 
HitTers, Juan Carlos. Técnica de los recursos extraordinarios y de la casación, $2^{\mathrm{a}}$ ed., La Plata, Editora Platense, 1998.

Houaiss, Antônio; VILlar, Mauro de Salles. Dicionário Houaiss da língua portuguesa. Rio de Janeiro, Objetiva, 2001.

JAy, John; HAmilton, Alexander; MAdison, James. The federalist on the new Constitution, written in the year 1788, Hallowell, Glazier, Masters \& Smith, 1837.

Jolowicz, J. A. "The role of the Supreme Courts at the national and international level: General Report" (relatório geral ao Congresso Internacional de Direito Processual de Thessaloniki), in The role of the Supreme Courts at the national and international level (org. Pelayia Yessiou-FALTSI), Thessaloniki, Sakkoulas Publications, 1998.

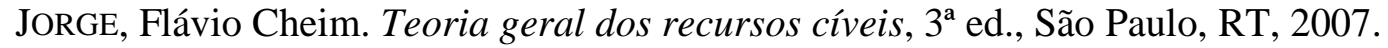

KNIJNIK, Danilo. O recurso especial e a revisão da questão de fato pelo Superior Tribunal de Justiça, Rio de Janeiro, Forense, 2005.

LACERDA, Galeno. "Críticas ao prequestionamento", in Revista dos Tribunais, v. 758, ano 87, dez./98, p. 68. . "O Código e o formalismo processual", in Revista da Ajuris, v. 28, ano 10, jul./1983, p. 7.

LEITE, Clarisse Frechiani Lara. Prejudicialidade no processo civil, São Paulo, Saraiva, 2008.

LeONel, Ricardo de Barros. Causa de pedir e pedido: o direito superveniente, São Paulo, Método, 2006. 
LESSA, Pedro. Do poder judiciário, Rio de Janeiro, Livraria Francisco Alves, 1915.

LIEBMAn, Tullio E. "Sui poteri del giudice nella questione di diritto ed in quella di fatto" (Estratto da La Corte di Cassazione, n. 2, 10 feb. 1925), in Sraffa Miscellanea, v. 86, n. 1-22, Roma, Tipografia del Senato del dott. G. Bardi, 1925.

LOPES, Bruno Vasconcelos Carrilho. Honorários advocatícios no processo civil, São Paulo, Saraiva, 2008.

LOPES, João Batista. "Recurso Especial - Distinção entre reexame e revaloração da prova Diferença entre fato e qualificação jurídica do fato", in Revista Dialética de Direito Processual, n. 60, mar./2008, p. 113.

Tutela antecipada no processo civil brasileiro, $4^{\mathrm{a}}$ ed., São Paulo, RT, 2009.

LuCon, Paulo Henrique dos Santos. "Art. 515, § $3^{\circ}$, do Código de Processo Civil, ordem pública e prequestionamento", in Os poderes do juiz e o controle das decisões judiciais Estudos em homenagem à Professora Teresa Arruda Alvim Wambier (coord. JosÉ M. GARCIA MEdinA et al.), São Paulo, RT, 2008.

MACIEL, Adhemar Ferreira. "Mandado de segurança. Direito líquido e certo", in Revista da Ajuris, v. 73, ano 25, jul./98, p. 14.

MAdisOn, James; JAY, John; HAMILTON, Alexander. The federalist on the new Constitution, written in the year 1788, Hallowell, Glazier, Masters \& Smith, 1837.

MANCuso, Rodolfo de Camargo. Recurso extraordinário e recurso especial, $10^{\mathrm{a}}$ ed., São Paulo, RT, 2007.

Marcato, Antonio Carlos. Procedimentos especiais, 12a ed., São Paulo, Atlas, 2006. 
MARINONI, Luiz Guilherme. "Ações repetitivas e julgamento liminar", in Revista Magister de direito civil e processual civil, v. 14, set-out./06, p. 5. "Aproximação crítica entre as jurisdições de civil law e de common law e a necessidade de respeito aos precedentes no Brasil", in Revista Forense, v. 401, jan.-fev./2009, p. 259.

"Reexame da prova diante dos recursos especial e extraordinário", in Revista de Processo, n. 130, ano 30, dez./2005, p. 19.

MARINONI, Luiz Guilherme; MITIDIERO, Daniel. Repercussão geral no recurso extraordinário, São Paulo, RT, 2007.

MARTINS-Costa, Judith. "O direito privado como um 'sistema em construção' - as cláusulas gerais no projeto do código civil brasileiro", in Revista dos Tribunais, v. 753, ano 87, julho/98, p. 24.

MARTY, Gabriel. La distinction du fait et du droit: Essai sur le pouvoir de contrôle de la Cour de cassation sur les Juges du fait, Paris, Recueil Sirey, 1929.

Matos PeiXoto, José Carlos de. Recurso extraordinário, Rio de Janeiro, Freitas Bastos, 1935.

MEDinA, José Miguel Garcia. O prequestionamento nos recursos extraordinário e especial, $2^{\mathrm{a}}$ ed., São Paulo, RT, 1999.

- Prequestionamento e repercussão geral: e outras questões relativas aos recursos especial e extraordinário, $5^{\mathrm{a}}$ ed. (da obra $O$ prequestionamento nos recursos extraordinário e especial), São Paulo, RT, 2009.

. "Variações recentes sobre os recursos extraordinário e especial Breves considerações", in Processo e Constituição - Estudos em homenagem ao Professor José Carlos Barbosa Moreira (coord. LuIz FuX et al.), São Paulo, RT, 2006. 
MeIRELLES, Hely Lopes. Mandado de segurança, $23^{\mathrm{a}}$ ed. (atualizada por Arnoldo Wald e Gilmar Ferreira Mendes), São Paulo, Malheiros, 2001.

MendonÇa Lima, Alcides de. Introdução aos recursos cíveis, $2^{\mathrm{a}}$ ed., São Paulo, RT, 1976.

Micheli, Gian Antonio. “Teoria Geral da Prova”, in Revista de Processo, n. 3, ano I, jul.set./1976, p. 161 (trad. port. de Arruda Alvim).

MitidiERO, Daniel. "A multifuncionalidade do direito fundamental ao contraditório e a improcedência liminar (art. 285-A, CPC): resposta à crítica de José Tesheiner”, in Revista de processo, v. 144, fev./07, p. 105.

MitidiERO, Daniel; MARINONI, Luiz Guilherme. Repercussão geral no recurso extraordinário, São Paulo, RT, 2007.

Monaghan, Henri P. "Constitutional fact review", in Columbia Law Review, vol. 85, n. 2, mar./1985, p. 229.

Moniz de Aragão, Egas D. Comentários ao Código de Processo Civil, II, 10ª ed., Rio de Janeiro, Forense, 2005.

dez./1994, p. 37.

Morales Molina, Hernando. Técnica de casación civil, Bogotá, Lerner, 1963.

MORELlo, Augusto M. "Recursos extraordinarios: visión comparada brasileña y argentina", in Revista de Processo, n. 79, ano 20, jul.-set./1995, p. 10.

MORRIS, Clarence. "Law and fact", in Harvard Law Review, n. 55, 1941, p. 1.303. 
NALin, Paulo; CAMBI, Eduardo. "O controle da boa-fé contratual por meio dos recursos de estrito direito", in Aspectos polêmicos e atuais dos recursos cíveis - e outros meios de impugnação às decisões judiciais (coord. Nelson NerY JR. e TERESA ARRUdA AlviM WAMBIER), São Paulo, RT, 2003.

NEGRÃo, Theotonio. “Técnica do recurso extraordinário no cível”, in Revista dos Tribunais, v. 602, ano 74, dez./1985, p. 9.

NEGRÃo, Theotonio; GouvÊA, José Roberto Ferreira; Bondioli, Luis Guilherme Aidar (com a colaboração de). Código de Processo Civil e legislação processual em vigor, $41^{\mathrm{a}}$ ed., São Paulo, Saraiva, 2009.

2009.

NERY JR., Nelson. "Questões de ordem pública e o julgamento do mérito dos recursos extraordinário e especial: anotações sobre a aplicação do direito à espécie (STF 456 e RISTJ 257)", in Os poderes do juiz e o controle das decisões judiciais - Estudos em homenagem à Professora Teresa Arruda Alvim Wambier (coord. José M. GARCiA MEdina et al.), São Paulo, RT, 2008. . Teoria Geral dos Recursos, 6a ed., São Paulo, RT, 2004.

Nery Junior, Nelson; Nery, Rosa Maria de Andrade. Código de Processo Civil comentado e legislação extravagante, 10a ed., São Paulo, RT, 2007.

NEves, Daniel Amorim Assumpção. "Recurso contra a sentença de improcedência liminar (art. 285-A do CPC) e o juízo de retratação", in Revista Dialética de Direito Processual, n. 54, set./07, p. 47.

NiEVA FenOlL, Jordi. "La relevancia social de la casación: la importancia del ius litigatoris", in Revista de Processo, n. 147, ano 32, maio/2007, p. 97. 
Nunes, Castro. Teoria e prática do Poder Judiciário, Rio de Janeiro, Forense, 1943.

Oliveira, Carlos Alberto de. "Recursos extraordinários: juízo de admissibilidade - CF, artigos 102, III, e 105, III, alíneas a”, in Revista Jurídica, v. 249, julho/98, p. 131.

PACHECO, José da Silva. "Julgamento da causa, pelo STF, após o conhecimento do recurso extraordinário", in Revista dos Tribunais, v. 567, ano 72, jan./1983, p. 250.

PALACIO, Lino Enrique. Manual de derecho procesal civil, $18^{\mathrm{a}}$ ed., Buenos Aires, AbeledoPerrot, 2004.

PIMEnTEl, Wellington Moreira. Comentários ao Código de Processo Civil, III, São Paulo, RT, 1975.

Pimentel SouZA, Bernardo. Introdução aos recursos cíveis e à ação rescisória, $4^{\mathrm{a}}$ ed., São Paulo, Saraiva, 2007.

PINTO, Nelson Luiz. Recurso especial para o STJ, 2a ed., São Paulo, Malheiros, 1996.

PomPEDDA, Mario F. Studi di diritto processuale canonico, Milano, Giuffrè, 1995.

Pontes de Miranda, Francisco Cavalcanti. Comentários à Constituição de 1967 com a emenda n. 1, de 1969, t. IV, $2^{\text {a }}$ ed., São Paulo, RT, 1970.

Proto PISANI, Andrea. Lezioni di diritto processuale civile, 2a ed., Napoli, Jovene, 1996. ."Crisi della Cassazioni: la (non più rinviabile) necessita di una scelta", in Revista de Processo, n. 157, ano 33, mar./2008, p. 261. 
PRÜTtING, Hans. "A admissibilidade do recurso aos tribunais alemães superiores", in Revista de Processo, n. 9, ano 3, jan.-março/1978, p. 153.

PuOLI, José Carlos Baptista. Os poderes do juiz e as reformas do processo civil, São Paulo, Juarez de Oliveira, 2002.

REALE, Miguel. "Julgamento antecipado da lide. Cerceamento de defesa. Inexistência, se o objeto da lide já se encontra esclarecido. Fundamentação de uma sentença: silogismo complexo", in Revista de Processo, v. 48, ano 12, out.-dez./87, p. 184.

. Filosofia do direito, $5^{\mathrm{a}}$ ed., São Paulo, Saraiva, 1969.

. Lições preliminares de direito, $27^{\mathrm{a}}$ ed., São Paulo, Saraiva, 2002.

. "Visão geral do novo Código Civil", in Revista dos Tribunais, v. 808, ano 92,

fev./2003, p. 11.

REINALDO, Demócrito Ramos. "O recurso especial e as decisões interlocutórias desafiadas por agravo de instrumento", in Revista dos Tribunais, v. 715, ano 84, maio/95, p. 56.

RIBEIRO DE OlIVEIRA, Eduardo. "Prequestionamento", in Aspectos polêmicos e atuais dos recursos cíveis de acordo com a Lei 9.756/98 (coord. TERESA ARRUDA AlvIM WAMBIER e NeLSON NeRY JR.), São Paulo, RT, 1999.

. "Recurso especial", in Temas de direito: homenagem ao

Ministro Humberto Gomes de Barros (coord. RenAtA BARBosA Fontes), Rio de Janeiro, Forense, 2000.

"Recurso especial - algumas questões de admissibilidade", in

Recursos no Superior Tribunal de Justiça (coord. SÁlvio DE FIGUEIREdo TEIXEIRA), São Paulo, Saraiva, 1991.

RoENICK, Hermann H. C. "A Súmula n. 7 do STJ e o reexame em sede de recurso especial da prova produzida com a petição inicial do mandado de segurança", in Revista da Ajuris, v. 73, ano 25, jul./98, p. 336. 
RosAS, Roberto. "A causa como pressuposto do recurso", in Recursos no Superior Tribunal de Justiça (coord. SÁlvio de Figueiredo TeIXeira), São Paulo, Saraiva, 1991.

ROSENBERG, Leo. Lehrbuch des deutschen Zivilprozessrechts, t. II, 5 ${ }^{\mathrm{a}}$ ed., Munique-Berlim, Beck'sche, 1951, trad. esp. de Angela Romera Vera, Tratado de derecho procesal civil, Buenos Aires, EJEA, 1955.

Rosito, Francisco. Direito probatório: as máximas de experiências em juízo, Porto alegre, Livraria do Advogado, 2007.

SAntos, Francisco Cláudio de Almeida. "Recurso especial - visão geral", in Revista de Processo, v. 56, ano 14, out.-dez./89, p. 122.

SATTA, Salvatore. Diritto processuale civile, $2^{\mathrm{a}}$ ed., Padova, CEDAM, 1950.

SCARPinella Bueno, Cassio. Curso sistematizado de direito processual civil, v. 2, tomo I, $2^{\mathrm{a}}$ ed., São Paulo, Saraiva, 2009.

SChwaRTZ, Bernard. Direito constitucional americano, Rio de Janeiro, Forense, 1966 (trad. port. de Carlos Nayfeld).

Schwartz, Germano; DeZorzI, Diego. "A história da Corte Suprema no Brasil: da Casa da Suplicação até a criação do Supremo Tribunal Federal”, in Revista da Ajuris, v. 112, ano 35, dez./08, p. 101.

SicA, Heitor Vitor Mendonça. Preclusão processual civil, São Paulo, Atlas, 2006.

. "Questões velhas e novas sobre a inversão do ônus da prova (CDC, art. 6, VIII)", in Revista de Processo, v. 146, ano 32, abril/07, p. 49. 
SILVA, José Afonso da. Do recurso extraordinário no direito processual brasileiro, São Paulo, RT, 1963.

SILVA, Vanderlei Arcanjo da; GouvÊA, José Roberto Ferreira. "Quantificação dos danos morais pelo Superior Tribunal de Justiça”, in Dano moral e sua quantificação (coord. SÉRGIO Augustin), $4^{\mathrm{a}}$ ed., Caxias do Sul, Editora Plenum, 2007.

STEIN, Friedrich. El conocimiento privado del juez, 2a ed., Madrid, Centro de Estudios Ramon Areces, 1990 (trad. esp. de Andrés de la Oliva Santos).

TALAMINI, Eduardo. "Repercussão geral em recurso extraordinário: nota sobre sua regulamentação", in Revista Dialética de Direito Processual, n. 54, set./2007, p. 56.

TANiguchi, Yasuhei. “O Código de Processo Civil japonês de 1996: um processo para o próximo século?", in Revista Forense, v. 350, abril-maio-junho/2000, p. 149 (trad. port. de José Carlos Barbosa Moreira).

TARUFFO, Michele. La motivazione della sentenza civile, Padova, CEDAM, 1975.

. "Senso comum, experiência e ciência no raciocínio do juiz", in Revista Forense, v. 355, maio-junho/2001, p. 101 (trad. port. de Cândido Rangel Dinamarco).

. "The role of the Supreme Courts at the national and international level: Civil Law countries", in The role of the Supreme Courts at the national and international level (org. Pelayia Yessiou-FAltsi), Thessaloniki, Sakkoulas Publications, 1998.

TARuffo, Michele; Comoglio, Luigi Paolo; Ferri, Corrado. Lezioni sul processo civile, v. I, $4^{\mathrm{a}}$ ed., Bologna, Il Mulino, 2006.

TeIXEIRA, Sálvio de Figueiredo. "O recurso especial e o Superior Tribunal de Justiça", in Recursos no Superior Tribunal de Justiça (coord. SÁlvio DE FigueIREdo TEIXEIRA), São Paulo, Saraiva, 1991. 
Theodoro Júnior, Humberto. As novas reformas do Código de Processo Civil, Rio de Janeiro, Forense, 2006.

Curso de direito processual civil, v. I, 47ª ed., Rio de Janeiro,

Forense, 2007.

Dano moral, $5^{\text {a }}$ ed., São Paulo, Juarez de Oliveira, 2007.

. "Prova. Princípio da verdade real. Poderes do juiz. Ônus da

prova e sua eventual inversão. Provas ilícitas. Prova e coisa julgada nas ações relativas à paternidade (DNA)", in Revista de direito privado, v. 17, ano 5, jan.-março/04, p. 9.

Terras particulares: demarcação, divisão, tapumes, $3^{\mathrm{a}}$ ed.,

São Paulo, Saraiva, 1992.

. "Tutela antecipada. Evolução. Visão comparatista. Direito

brasileiro e direito europeu", in Revista de Processo, v. 157, ano 33, mar./08, p. 129.

Tornaghi, Hélio. Comentários ao Código de Processo Civil, I, São Paulo, RT, 1974.

Vidigal, Luís Eulálio de Bueno. Comentários ao Código de Processo Civil, VI, $2^{\mathrm{a}}$ ed., São Paulo, RT, 1976.

VILlar, Mauro de Salles; HouAISs, Antônio. Dicionário Houaiss da língua portuguesa. Rio de Janeiro, Objetiva, 2001.

WAMBIER, Teresa Arruda Alvim. "A influência do contraditório na convicção do juiz: fundamentação de sentença e de acórdão", in Revista de Processo, v. 168, ano 34, fev./09, p. 53.

. "Distinção entre questão de fato e questão de direito para fins de cabimento de recurso especial”, in Ajuris, ano XXV, n. 74, nov./1998, p. 253.

Omissão judicial e embargos de declaração, São Paulo,

RT, 2005.

. "Recurso especial e ações de família", in Revista de

Processo, v. 176, ano 34, out./09, p. 36. 
Recurso especial, recurso extraordinário e ação rescisória,

$2^{\mathrm{a}}$ ed., São Paulo, RT, 2008.

Watanabe, Kazuo. “Acesso à justiça e sociedade moderna”, in Participação e processo (coord. ADA PELLEGRINI GRINOVER et al.), São Paulo, RT, 1988.

. Controle jurisdicional e mandado de segurança contra atos judiciais, São

Paulo, RT, 1980.

. Da cognição no processo civil, $3^{\mathrm{a}}$ ed., São Paulo, Perfil, 2005.

WiLloughby, Westel Woodbury. The Constitutional Law of the United States, vol. I, Nova York, Baker, Voorhis \& Company, 1910.

YARSHELl, Flávio Luiz. Ação rescisória: juízos rescindente e rescisório, São Paulo, Malheiros, 2005. "Breve 'revisita' ao tema da ação rescisória", in Revista de Processo, v. 79, ano 20, jul.-set./1995, p. 241.

YoshiKawA, Eduardo Henrique de Oliveira. "Distinção entre questão de fato e questão de direito: reexame e valoração da prova no recurso especial", in Revista Dialética de Direito Processual, n. 43, out./2006, p. 29.

ZAVASCKI, Teori Albino. Antecipação da tutela, 6a ed., São Paulo, Saraiva, 2008. 